\title{
AN ANALYSIS OF CODE MIXING IN A DEBATE ACTIVITY AS PART OF ENGLISH CLUB PROGRAMS AT SMAN 2 BENGKULU CITY
}

\author{
Darpeli Eli Zetri \\ Universitas Bengkulu \\ Darpelielizetri@gmail.com \\ Arasuli \\ Universitas Bengkulu \\ Arasuli.msi@gmail.com \\ Mazrul Aziz \\ Universitas Bengkulu \\ mazrulazizma@gmail.com
}

\begin{abstract}
The aim of this research is to investigate code mixing produced by the students of 'Debate Activity as part of English Club' program at SMAN 2 Bengkulu city. The design are descriptive quantitative and qualitative. The subject is eight students who are involved in the debate activity. The instruments consist of observation checklist and interview. The data are taken from the recording of the debate activity on $18^{\text {th }}$ May 2018. In analyzing the data, the researcher trancribes the recording, classifies the data which can be categorized as code mixing based on Fasold's theory (2004), analyzed the reasons why the students mixed the code, made a percentage and draw conclusion. The result showed that there were two types of code mixing applied by the students in debate activities. The type of code mixing appeared were insertion of word code mixing (56.6\%) and insertion of phrase code mixing (43.3\%). The data of interview were some reasons why the students mixed the code in the debate activity, namely repetead used for correction, because of unintentionally, and because of less vocabulary. However, the code mixing could not be denied in debate activity as part of English club programs.
\end{abstract}

Keywords: Code mixing, Debate activity, English club

\section{INTRODUCTION}

Language has an important part in human life because it is a means of communication among human beings in this world when people want to express him or herself. So, the language system must be utilized. In addition, language is a mediator used by people to transfer what they have in their mind to others. They use language to avoid misunderstanding, miscommunication, misinterpretation, misperception, misreading information and misinteraction. This is related to Wardhaugh's definition of language as a system of arbitrary vocal symbol used for human communication (Wardhaugh, 1972:3, in Brown, 1987:4).

English as a foreign language is very important to master, because it plays an international role among many countries in the world. In addition, English is an interesting language to learn. This is because English is a language that includes the most commonly used and in the world of work mastery of this language is necessary. If someone is proficient in English, it could be added value in 
finding work. Therefore, English is one of the most important languages in the world of education, especially in Indonesia. Although English as a foreign language, but English is contained in the curriculum of elementary, junior, and high school education. Besides being a mandatory or much needed international language, English is also a scientific language. Many people create scientific papers or journals in English. This is also the reason why English is very important language.

In bilingual and multilingual societies, people may produce certain codes. They may use code mixing or code switching in their conversation. The lender (in Suwito, 1985:76) differentiates code switching and code mixing. If an utterance is switched from one language to another language supporting a distinctive function, it is called code switching. Conversely, if an utterance, either phrase or clause, consist of a clause or phrase does not support a distinctive function it is called code mixing.

In addition, the reason why the researcher was interested in researching the use of code mixing in students is when the researcher visited in SMA 2 Bengkulu City. The researcher saw there are some students who make a group in learning English. This group of learning is also one of the extracurricular in high school. This group of learning is named English Club. This activity has schedule on Friday and Saturday at 10 am until $5 \mathrm{pm}$, after the student finished their school regular activity.

Based on observation of this research in English Club at SMAN 2 Bengkulu City, the researcher found some of problem that many students use mixed language between English and Indonesian. Their spoken or written products usually contain code mixing. It caused that the students have difficulty in English vocabulary. Furthermore, when they do not know the English word, they will use Indonesian word. Specifically, the problem found in debate as part of English Club. When they speak up and deliver their opinion, they are difficult to speak English fluently. Sometimes, they use Indonesian to deliver their idea or opinion completely. Based on that problems, the researcher interests to analyze the code mixing used by students. It purposed to know the types of code mixing used by students in English Club and to explain the students' reasons in using code mixing.

Related to the language usage at English Club, the students use English as a foreign language. In communication, sometimes they take part of English into Indonesian or vice versa. It is because they talk in natural English and sometime they mix their utterances by using English and Indonesian language. This phenomenon shows that there is a "chaos" in using language.

When the code-mixing features appear, the indications are the parts of speeches insert into other language without any separation function from the original one of the language where the parts come from. The parts become one in the language it inserts and generally it has only one function. In maximal condition, code mixing is convergence linguistic that the parts come from some languages and each part leaves the previous function and supports the function of the language itself.

Generally, with several motives, code mixing performs in daily life. Professions, social class, economy level, age, and sex and others are certain motives for people to have code mixing communications as sentenced by Patteda (1987:1). For example, when students explain something to another one, there are parts of language words, phrases and clauses - that suddenly come from their own language 
into Indonesian or English into Indonesian.

Such sociolinguistic event can happen in various moments. The support aspect that can be reason to make an observation related the phenomenon. They are the students with different ethnic, social and cultural background. This cannot be separated from the bilingual or multilingual society because each ethnic has its own language. Moreover, they use Indonesian, and they learn English. It means that each of them has three languages namely regional language (mother language), national language, and English. As an education institutes, SMAN 2 Bengkulu City teaches English subject for the students to increase that their ability in English, and the school gives additional time for English learning.

In fact, lack of English vocabulary, embarrassed when speaking English, and afraid to make mistakes in their conversation are dominant problem faced by the students. Therefore, code mixing is one of the ways to help the students in using English in their presentation/conversation easily.

There are some previous studies similar with this research. First, Kurniawati (2005) with her research entitled "A Linguistic Study on Indonesian - English Code Mixing Used in HAI Magazine". She found the kinds of code mixing. There were words (84 data), which were classified into noun (84 data), pronouns (15 data), verbs (3 data), adverbs (2 data), adjectives (14 data), conjunctions (2 data), reduplications ( 1 datum), and hybrids (10 data). The form belong to syntactic form were phase and clause (10 data).

Second, Subekti's research (2006) entitled "An Analysis of Indonesian English Code Mixing Used in Tempo Magazine". The result of his analysis showed those there 50 words, 12 phrases, and 3 idioms. The type of code mixing was outer code mixing in English. The reasons of using the code were need filling motive, prestige filling motive, and other reasons such as to complain, to give respect, etc.

Third, Zahra (2012) with this research entitled "An Analysis of CodeMixing in Television Commercials". His research concerned to the influences of code-mixing generally for the viewer and server. It also purposes to know what the impact of code mixing on the viewers itself.

Specifically, this research will be differnt from the previous study in term of content and the research object. So that the researcher will conduct a research entitled "The Analysis of Code Mixing in a Debate as Part of English Club Programs in SMAN 2 Bengkulu".

\section{METHOD}

This research aims to expose the sentence that appears in conversation from inside the sentence itself. The design of this research is descriptive, using quantitative as well as qualitative data. The quantitative data shows in order to show the percentage of occurrences, whereas qualitative data shown in order to describe the reasons of the students use code mixing in their conversation. Stewart (1990) stated that descriptive quantitative and qualitative researches are two major approaches to research methodology in social sciences. The data result mostly in descriptive explanation.

The subject of this research is 8 students. They are all of Debate as part of English Club member in SMAN 2 Bengkulu City, consist of 5 males and 3 females. The students have joined in English club for 1-2 years, and have been won the $2^{\text {nd }}$ winner on Debate News 2016 in Bengkulu, $1^{\text {st }}$ Best Speaker News 2016 in Bengkulu, $1^{\text {st }}$ Champion MEDCT 2016 in Bengkulu, $2^{\text {nd }}$ Best Speaker CED 2017 in Bengkulu, $3^{\text {rd }}$ Best Speaker CED 2017 in Bengkulu, $3^{\text {rd }}$ 
Champion CED 2017 in Bengkulu, $3^{\text {rd }}$ Champion TT Expo Jambi 2017, $3^{\text {rd }}$ Best Speaker EDC 2017 in Curup, and $1^{\text {st }}$ Debate CED 2018 in Bengkulu.

In this research, the researcher will use instruments to be employed in this study. The instruments are observation checklist and interview. The observation checklist will answer the research question number 1 to know what types of the using code mixing. Meanwhile, interview will answer the question number 2 to know the reasons of the using code mixing.

The instrument for collecting the data in this research is a set of observation checklist. Observation checklist is a method or means those analyze and hold a systematic record of the behaviour by seeing or observing individuals or groups directly (Arikunto: 2006).

The research used tape recorder to collect the data both in English Club while the debate activities were taking place. In the debate community, the researcher just turned on the hidden tape recorder to have genuine speech data and the researcher will noted sentences by the students and classifying into a form to know types that the students used.

After that, the researcher will make transcript form of the record, this document to know what types that students used at debate activity of the English Club students.

In this research, the researcher also uses interview as the instrument. An interview is a conversation between two or more people and takes place between the speaker and the interviewer (Arikunto: 2006). The purpose of the interview is to get the information in which the interviewer asks questions to be answered by the person to be interviewed.

In this study, the researcher will be assisted some friends from EDSA. Here, the researcher and co-researcher will observe the debate activities are done, the possibility of matching the results of observations obtained.

The data were taken from the record. This data were analyzed according to the Fasold's theory as cited by Chaer and Agustine (2004). Furthermore the data were also analyzed to answer the research question number 1 about the types of code mixing used by the students of English Club.

After gaining the all data needed that contains of code mixing. The researcher put the data into groups depend on the form. Since differentiating the code mixing, the researcher applies the theory stated by Fasold as cited in Chaer and Agustina (2004). This theory divides code mixing based on its grammatical form.

This research will use proportion formula to analyzing data. The data will be calculated by using the percentage techniques formula as follow (Sudijono in Gustini, 2016):

$$
P=\frac{F}{N} \times 100 \%
$$

This research also used SpearmanBrown formula to avoid the degree of subjectivity in making judgment and analyze the reliability between reseacher and co-reseacher. The formula was published by SpearmanBrown (1960). Spearman-Brown coeficient is a statistical measure of inter-rater agreement for quantitative items. (Arikunto, 2002)

The formula is :

$$
r_{x y}=\frac{n \sum \boldsymbol{x} \boldsymbol{y}-\left(\sum \boldsymbol{x}\right)\left(\sum \boldsymbol{y}\right)}{\sqrt{\left\{\boldsymbol{n} \sum \boldsymbol{x}^{2}-\left(\sum \boldsymbol{x}\right)^{2}\right\}\left\{\boldsymbol{n} \sum \bar{y}^{2}-\left(\sum \boldsymbol{y}\right)^{2}\right\}}}
$$

\section{RESULT AND DISCUSSION}

\section{Results}

In this chapter, the researcher identified code mixing done by the students in English Club at SMAN 2 Bengkulu City. 
The researcher has already reviewed the relevant distinctions that are made to point out the differences of the types of code mixing based on Fasold's theory. Then, the researcher explains about the reasons of using code mixing.

The whole data were transcript from the students utterances having debate activities at SMAN 2 Bengkulu city at $18^{\text {th }}$ May 2018. It is presented in the form of tables. The data shows that the two types of code mix, such as insertion of word code mixing and insertion of phrase code mixing. However, it appeared that insertion of word code mixing tends to be the most frequent type of code mixing used in the debate activities. The findings are presented in the table below:

Tabel 1. Code Mixing Used in a Debate Activity

\begin{tabular}{|c|l|c|c|}
\hline No. & $\begin{array}{l}\text { Types of } \\
\text { Code Mixing }\end{array}$ & $\begin{array}{c}\text { Frequency } \\
\text { (F) }\end{array}$ & Percentage \\
\hline 1. & $\begin{array}{l}\text { Insertion of } \\
\text { Word Code } \\
\text { Mixing }\end{array}$ & 13 & $56.6 \%$ \\
\hline 2. & $\begin{array}{l}\text { Insertion of } \\
\text { Phrase Code } \\
\text { Mixing }\end{array}$ & 10 & $43.4 \%$ \\
\hline \multicolumn{2}{|c|}{ Total } & 23 & $100 \%$ \\
\hline
\end{tabular}

The table above indicates the total of code mixing in A Debate Activity as part of English Club Programs in SMAN 2 Bengkulu City. There are 23 cases of code mixing and done by the students. They are 13 (56.6\%) cases of insertion of word code mixing and 10 (43.4\%) cases of insertion of phrase code mixing. Among those two mixing, the most used is insertion of word code mixing.

The data present a very rich description of speakers' use of code mixing as a personal communication strategy. It was taken from the interview followed by the analysis of the researcher. The data clearly illustrate how speakers organized, enchained and enriched their speech trough code mixing strategies such as repetition used for clarification, intention of clarifying the speech content for interlocutor, and because of real lexical need.

These findings are discussed below. 1.Repetition used for clarification

One of the reasons for them to use in the debate activity was repetition of information. It was normally happened along the time when they do debate activity. Their goal was to make a better understanding from the listeners because they were not speaking for themselves but for the listeners.

2. In the debate activity, there are some students who mix their code because of unintentionally. For example, in interview at $18^{\text {th }}$ May 2018, the students said that "I mix my language by accident". It means they used Indonesian language in their speech unintentionally.

3. Because less of vocabulary.

According to all of the students in debate activity, as English-Indonesian bilinguals, they have a word that is lacking in English. Then they would find it easier to say it in Indonesian as they said that "I am mixing my language because there is a vocabulary that I do not know and forget". Moreover, vice versa, when they had a word that is lacking in Indonesian, they would use the English term. To convey clear messages and avoid vague meaning, interlocutors may mix his/her language into another language.

Comparing this present research to the previous research to the previous research, there are some previous research which are in line with this present research, though the subject of previous research was different, such as code mixing in HAl magazine, Tempo magazine, and Television commercials. The first previous study comes from Kurniawati (2005) with the research entitled " A linguistic study on Indonesian - English code mixing used 
in HAI magazine", the second is from Subekti (2006) which entitled "An analysis of Indonesian English code mixing used in Tempo magazine", and the last is from Zahra (2012) which the research entitled "An analysis of code mixing in television commercials".

From some of the previous studies above, they have same result which is revealed that insertion of word code mixing tends to be most frequently type used in conversation, then continued by insertion of phrase code mixing as the least frequently. The probably reason why they have the similar result was of they are all from English Club and they are capable in using both English in Indonesian so that they often used them together when speaking. Then, the researcher also assumed that one of the reasons triggering them to do insertion of word code mixing is because of the lack of vocabulary in target language. As pointed out by Belly R.T (1976), the choices of content, but are 'discourse strategies', that is, the choices are used more to accomplish the speaker's intents than conveying referential meaning. When a language learner lacks a word in English due to limited vocabulary, this person tends to code mixing by using the lexical component from his/her first language instead of English.

Speakers mix into another language because they are more familiar with the lexical items in that particular language than in their native language. Chaer (2004) explains that the speakers mix their code whenever they are more familiar with words, phrases, or sentences in English. This view is also found in Holmes (1992), whose interview results indicate that the subjects normally mix to the language to which they are most accustomed.

Meanwhile, this result was different from Kurniawati (2005) who analyzed code mixing applied in HAI magazine. His result finding revealed that insertion of phrase code mixing is mostly used in television commercials, this is because the subject of both research were different. The subject of the present research were the students of debate activity, while the subject of the previous research were HAI magazine where the ability of speak of both subject was different. Because insertion of phrase code mixing involves at a clause or sentence boundary, it can be thought of as requiring greater fluency in both languages that insertion of word code mixing. In this case, in the magazine is mostly proficient in languages, so that is why the insertion of phrase code mixing is more dominating than insertion of word code mixing.

In this result, they might use this when they have words lacking in English or on the opposite when they try to balance the lack of equivalent lexicons in interlocutor's language (Hymes, 1974). As the statement mentioned by the students that they couldn't justify all the listeners are good in English. The target of the program might be the college students but it couldn't be said that no one of the excluded people were not listening to them. In another words, to convey clear messages and avoid vague meaning, the students code mix their language into Indonesian language. In addition, the use of code mixing here can be attributed to the need for a clarification of the message and occurs when a speaker wants to make clearer what he or she is talking about.

In the other cases, to maintain the clarifying of their speech, the students also code mix the reason of clarifying their speech, so that the listeners will understand it better. They sometimes use both of the languages (codes), English-Indonesian, to say the same message. Frequently, a message in one code is repeated in the other code literally. A repetition is not only served 
to clarify what is said, but also to amplify or emphasize a message. In line with this idea, they also used code mixing as an intention of clarifying the speech content for interlocutor. This actually has the same goal as it stated before that this happened by the reasons to make the better understanding of the listeners, but they did it in the other way. The speakers might change or modify the sentences into other sentences that actually have the same meaning.

\section{CONCLUSION AND SUGGESTION}

\section{Conclusions}

This study aimed to describe the types of code mixing performed by the students in English Club at SMAN 2 Bengkulu City and to find out the reasons and motivations influence the used of that English-Indonesian code mixing. Based on the findings, several conclusions could be drawn as follows:

First, there are two kinds of code mixing used by the students in English Club. They are insertion of word code mixing and insertion of phrase code mixing. The code mixing used most in the debate activity was insertion of word code mixing.

Second, the reasons of the students mixing their code were to repeatead used for clarification, because of unintentionally, and because of less vocabulary.

In conclusion, code mixing actually can be used as sociolinguistic tool to create a good communication, especially in English Club at SMAN 2 Bengkulu City. This could be an effective way since it is used to get the better understanding for the listener so that they can catch the idea easily without trying too hard to understand every utterance of the students. However, the phenomenon of code mixing and in this debate was already good because they had avoid main restriction that developed by Fasold as cited in Chaer and Agustine (2004), that is free morpheme constraint.

\section{SUGGESTIONS}

Based on the research result, the researcher would like to give some suggestions as follows:

First, for the learners, the researcher hopes that this research will give more information about the types of code mixing in Debate as part of English Club Activities and the reasons why they did it. The researcher expected that this research could be useful as additional academic reference especially when they will conduct the research in the same field.

Second, the researcher suggests to the other researchers who will conduct the research in the same field to do further research and analyze from another limitation such as code mixing occurrences between genders, code mixing among two different nationality, etc. Looking forward, more extensive and intensive research on the English Club could be carried out. The study with a longer time-span, a larger variety of English Club or in the school.

\section{REFERENCES}

Arikunto S, 2006. Prosedur Penelitian Suatu Pendekatan Praktik, ED Revisi VI, Penerbit PT Rineka Cipta, Jakarta.

Belly, R.T. 1976. Sociolinguistics: Goals, Approaches And Problems. London: B.T. Batsford Ltd.

Chaer, Abdul and Leonie Agustina. 2004. Sosiolinguistik Perkenalan Awal. Jakarta: PT. Rineka Cipta.

Holmes, Janet. 1992. An Introduction to Sociolinguistic. London and New York:Longman 
Hymes, Dell, 1974. Foundations in Sociolinguistics. Philadelphia: University of Pennsylvania Press

Kurniawati, 2005: A Linguistic Study on Indonesia - English Code Mixing Used in HAl Magazine.

Subekti, 2006: An Analysis of Indonesian English Code Mixing Used in Tempo Magazine.suwito, sosiolinguistik pengantar awal, surakarta : pengantar awal, 1985.

Suwito, 1985: Code Mixing and Code Switching, Jakarta.

Wardhaugh, Ronald. 1972. Introduction to linguistics. New York. University of Michigan

Wardaugh, Ronald. 1986. An Introduction to Sociolinguistics. United Kingdom: Wiley-Blackwell.

Zahra, 2012: An Analysis of Code Mixing in Televisian Commercials. Scholar of M.S English of Air University Islambad, Pakistan. 